\title{
Compensation of Chinese early childhood teachers: a preliminary study in Hong Kong, Shenzhen, Singapore, and Taipei
}

Hui Li

Correspondence: huili@hku.hk Faculty of Education, The University of Hong Kong, Pokfulam, Hong Kong

\begin{abstract}
This study compared the structure and level of Chinese teachers' compensation in public or non-profit-making early childhood settings in Hong Kong, Shenzhen, Singapore, and Taipei. Document analysis method was employed to compare the compensation structure, and two indicators were used to compare the pay level: (1) the Economist's Big Mac Index and (2) the house price-to-income ratio. The results indicated that: (1) Hong Kong employs a single-salary scheme, whereas the other cities use a mixture of competency-based plus performance-based compensation; (2) Taipei's compensation system features the most comprehensive structure, the highest hourly pay, and the shortest working hours, whereas Singapore's system features the lowest pay level and the longest working hours; and (3) Taipei's early childhood teachers have the strongest purchasing power in housing, whereas Singapore teachers have the weakest purchasing power in food and housing. Implications and suggestions are made to address the challenges facing the compensation of Chinese early childhood teachers.
\end{abstract}

\section{Background}

Compensation of early childhood teachers has become a global concern since the International Labor Organization (ILO) released the report on conditions of personnel in early childhood education in 2012. The ILO report indicated that early childhood educators all over the world suffered from low and irregular payments, fuelling high turnover in the workforce and resulting in a decline in the quality of early childhood education (ECE) (ILO 2012). This holds true especially in the United States where the annual turnover rate is $30 \%$ (Thornburg et al. 2005) and in Chinese societies where the rate is 50\% in Hong Kong ( $\mathrm{Li} 2012$ ) and 40\% in Shenzhen (Li et al. 2013), respectively. Such a high teacher turnover is harmful for young children, as empirical evidence indicated that classrooms with higher teacher turnover tended to have poorer social interactions and lower levels of engagement in play and learning activities (Howes and Hamilton 1993). Adequate compensation for early childhood teachers is needed because better compensated educators could provide higher quality education and lower teacher turnover (Thornburg et al. 2005; Whitebook et al. 2001). While many studies and reform suggestions have been made for a better teacher compensation system in North America (Rowland and Potemski 2009; Podgursky 2007; Podgursky and Springer 2007, 2011), few studies have been conducted in Chinese societies, where formal ECE

(C) 2014 Li; licensee Springer. This is an Open Access article distributed under the terms of the Creative Commons Attribution License (http://creativecommons.org/licenses/by/2.0), which permits unrestricted use, distribution, and reproduction in any medium, provided the original work is properly credited. 
has not been especially valued until very recently ( $\mathrm{Li}$ et al. 2010). Therefore, this study endeavors to understand how the early childhood teachers in four Chinese societies Hong Kong, Shenzhen, Singapore, and Taipei - are compensated.

\section{Compensation system of early childhood teachers}

There are three general terms concerning teacher pay: compensation, remuneration, and salary. Compensation, a term widely used in North American, is everything the company provides an employee with in exchange for work. It is the sum of four components - base salary, supplements, benefits, and deferred compensation (Rowland and Potemski 2009; Podgursky 2007; Podgursky and Springer 2007, 2011). Remuneration, widely used by the ILO (2012) and European countries, is interchangeable with the term 'compensation' in most contexts. Salary, what an employee can see on their paycheck, does not include any bonuses, benefits, or perks associated with the job. In this paper, compensation refers to the sum of base salary and all of the bonuses, benefits, and other payments (Podgursky and Springer 2007, 2011). For example, a typical compensation package may include health insurance, performance bonuses, vision and dental insurance, and retirement plans. Each of these has a cost to the company and a value to the employee. But since they are not listed in employee's paycheck, they could not be regarded as 'salary'.

In Chinese societies, teacher compensation consists of four components - base salary, allowance, bonus (incentives), and deferred compensation (including cash benefits and non-cash compensation) (Li et al. 2013). Base salary is often calculated by the qualification, ranking, service, and contribution. Allowances are monetary subsidies for additional expenses teachers may incur in their jobs and daily lives, including transportation, education of employee offspring, and general living expenses. Bonus (incentives) is additional reward given to teachers who excel in their performance, often taking the form of money or of gifts to motivate them to perform well in their jobs. Finally, cash-based benefits include the protections and perks given to teachers such as research and wedding fees, whereas non-cash compensation comes in the form of retirement pay (Li et al. 2013).

Around the world, there are many ways to compensate teachers for their work. However, little research has been conducted to examine early childhood teacher compensation systems, and the few studies that are readily available refer solely to how U.S. kindergarten teachers are compensated. The three most popular compensation methods adopted in the U.S. are the single-salary schedule, performance-based compensation (or merit pay), and competency-based compensation (Podgursky and Springer 2007, 2011; Rowland and Potemski 2009). The single-salary schedule was created in 1921 to provide a uniform system compensating teachers based on their levels of education and years of experience (Koppich 2008; Podgursky and Springer 2007). To this date, $96 \%$ of all U.S. school districts continue to use a single-salary schedule to pay their teachers (Podgursky 2007). This type of compensation has long been viewed as an equitable salary system by virtue of its objectivity, predictability, and non-competitive structure (Koppich 2008). However, it is now regarded as a system that is neither sensitive to market demands nor based on teacher performance (Rowland and Potemski 2009). 
Therefore, beginning in the 1980 's, performance-based compensation began to receive increased attention. Performance-based compensation refers to a pay scheme that is based on the teacher's performance in the classroom. A comprehensive evaluation system which includes multiple measures (e.g., classroom observations, student growth data, and portfolios of student work) is needed to precisely evaluate a teacher's performance (Rowland and Potemski 2009). Doing so takes into account factors other than credentials and years of experience, both of which have been shown by the Organisation for Economic Co-operation and Development (OECD) to be poor indicators of teachers' effectiveness (OECD 2012). In theory, it is fairer to reward teachers who perform well rather than paying all teachers equally, as merit pay can better motivate teachers and better connect school expenditure with school outcomes to build public support (OECD 2012). In practice, however, this method is difficult to achieve accurate evaluations because performance might not be determined objectively. In addition, evaluations may reduce cooperation among teachers, and teaching may become narrowly focused on the performance indicators being used (Rowland and Potemski 2009). In sum, performance-based pay is worth considering in some contexts; but making it work well and sustainably is a formidable challenge (OECD 2012; Rowland and Potemski 2009).

An alternative, competency-based compensation is also used to pay teachers. This pay system relates salary progression or a cash bonus to the display of 'competencies', including the acquisition of new knowledge or demonstration of an improved expertise or ability (Rowland and Potemski 2009). Different from performance-based pay, this system is not based on the achievement of specific results, such as targets and projects completed (Neathey and Reilly 2003). In practice, however, competency-based pay systems are rarely used in a pure form or as the only means for determining reward, as there are concerns about the attainment of agreed standards of competencies (Rowland and Potemski 2009). Instead, most cities, including those in East Asia, combine the competency-based and performance-related pay (Brown and Armstrong 1999; Li et al. 2013). This study will explore whether a fusion of performance-based and competencybased pay is really used to pay Chinese teachers.

An effective teacher compensation system should be sensitive to market demands and make teaching competitive with other professions in order to recruit, retain, and motivate the highest quality workforce (Podgursky and Springer 2007). Notably, the single-salary schedule dominating U.S. kindergartens is neither performance-based nor market-driven (Podgursky and Springer 2011); school leaders cannot modify a teacher's pay based on performance or on the realities of a changing labor market. In recent years, policymakers in the U.S. have turned their attention to performance-related and market-driven pay plans. As a result, there has been more research on teacher compensation in the ECE field in the United States. Still, little is known about how Chinese early childhood teachers are compensated for their work. This study therefore attempts to address this research gap.

\section{Compensation of Chinese early childhood teachers}

Chinese society is a particularly appropriate context to begin this study, as there has been a rise in academic interest, in public concern, and in governmental attention towards the 
ECE field in recent years ( $\mathrm{Li}$ et al. 2013). Numerous policies have been passed over the recent decade to make quality early childhood education more affordable and accessible to children in Hong Kong, China, and Singapore (Li et al. 2010). But low payments for teachers and high turnover rates have become a remarkable concern in Hong Kong and other Chinese societies. We need to understand whether Chinese teachers are compensated fairly and appropriately by comparing their compensation with those received by teachers working in similar cities within the region. Accordingly, we chose to compare the compensation structure and level of Chinese early childhood teachers in Hong Kong (Special Administrative Region of the People's Republic of China, PRC), Shenzhen (PRC), Singapore, and Taipei (Republic of China). All the cities are the capital of their own countries (or special administrative region), except for Shenzhen. Shenzhen was chosen to compare with Hong Kong as it is a good match in PRC, in terms of geographical and economical similarities. Hong Kong, Taipei, and Shenzhen belong to Greater China, vary greatly in terms of the provision and development of early childhood education. Singapore is a multinational country but is traditionally regarded as a Chinese society, as more than $70 \%$ of its population is Chinese ( $\mathrm{Li}$ et al. 2012). For comparison purposes, we focused only on the Chinese early childhood teachers (including teaching assistants) in the four cities in this study. Unlike American kindergartens that only receive 5- to 6-year-olds, kindergartens in Hong Kong, Shenzhen, and Taipei enroll young children aged 3 to 6 years. In Singapore, however, kindergarten just provides 3-h program to 5- to 6-year-olds, whereas childcare center caters to children aged 2 months to 6 years. To avoid misunderstanding and confusion, we chose to use the term Chinese early childhood teachers to refer to those practitioners working with children of 3 to 6 years in Singapore childcare centers and the public/non-profit kindergartens in other three cities in this paper. In this subsection, we will examine the structure and level of teacher compensation across the four cities.

In Hong Kong, all the kindergartens are privately run, either by non-governmental organizations, private enterprises, or individuals (Li et al. 2008). In 2012 to 2013 school year, there were 957 kindergartens, and most of them (83\%) are non-profitmaking kindergartens, the other $17 \%$ are private, independent kindergartens that are for profit (http://www.edb.gov.hk/en/about-edb/publications-stat/figures/kg.html). The educational authorities regularly issued a salary scale for kindergarten teachers, a single-salary schedule which was announced invalid when the government launched the 'pre-primary education voucher scheme' in 2007 ( Li et al. 2010). Many non-profit-making kindergartens, nevertheless, still followed this scale to pay the teachers, whereas the for-profit kindergartens do not.

In Shenzhen, most of the kindergartens are privately run and few of them are operated by educational authorities. In 2012 to 2013 school year, for instance, there were 1,186 kindergartens in the city, but only $5 \%(N=59)$ of them are public kindergarten, the other 1,127 (95\%) kindergartens are private ones (http://www.szeb.edu.cn/SZEB/ HTMLDynamic/YWTJT_494/201303/info44138.html). Public kindergartens follow the governmental salary scale to pay their teachers, whereas the private kindergartens do not have any pay scales (Li et al. 2013). Accordingly, early childhood teacher salaries vary greatly depending on whether the teacher is employed in a public kindergarten (where salaries are determined and protected by government regulations) or in a private kindergarten (where salaries are decided at the employers' discretion). 
In Singapore, there are about 1,000 childcare centers (CCC) and 500 kindergartens. CCC is a full-day pre-primary education program, catering to children aged 2 months to 6 years. Kindergarten is a 3-h program, catering to 5- to 6-year-olds who need to prepare for primary school. All the CCCs and kindergartens were privately run before 2014, often by business and social organizations, political parties, religious institutions, community foundations, and international schools (Ng 2011). The Ministry of Education in Singapore has started operations of five public kindergartens in January 2014, which can provide an appropriate program and reasonable fees. And ten more public kindergartens will be set up in the next few years (http://www.moe.gov.sg/education/ preschool/). Despite recent governmental efforts to better monitor the ECE system in Singapore, much of their ECE remained unregulated - including teacher compensation. Most of the early childhood teachers were underpaid, while many of whom were also not officially qualified or certified to teach young children (Ng 2011).

In Taipei, there are both public and private ECE services available to families. In 2013 to 2014 school year, for example, there are 711 kindergartens in the city, but only $21 \%$ ( $N 1=$ $148)$ of them are public ones, all the others $(N 2=563)$ are privately owned (http://www. doe.taipei.gov.tw/ct.asp?xItem $=71841049 \&$ ctNode $=33658 \& m p=104001$ ). Early childhood teacher salaries vary depending on whether the teacher is employed in a public kindergarten or in a private kindergarten. In particular, early childhood teachers employed by the governments are paid according to the national teacher compensation scale, whereas teachers in private kindergartens are paid at the employers' discretion.

There is a remarkable public-private dichotomy in teacher's pay in these Chinese cities. As shown in this comparison, the early childhood teachers in Shenzhen and Taipei public kindergartens are better paid compared to their counterparts in private kindergartens. In Hong Kong and Singapore, the teachers working in non-profitmaking kindergartens tend to be better paid compared to their counterparts in those for-profit kindergartens. Careful examination, however, is needed to determine whether this is the case and how early childhood teachers are paid. Given the fact that there are severe income disparities among for-profit, private kindergartens, this study focused on the compensation system in public (or non-profit in Hong Kong and Singapore) kindergartens. The primary objective is to provide a preliminary understanding of the compensation structure and level in early childhood education in these Chinese societies. However, it is important to note that the skewed sample of this study may not support more generic and precise comparison.

\section{Methods}

Document analysis method was employed to analyze the current compensation systems for public kindergarten (or its equivalent) teachers in the four cities. Additionally, two comparable indicators, the Big Mac Index and the house price-to-income ratio, were used to compare the real pay level and the exact purchasing power of early childhood teachers. We discuss each of the three measures in more detail below.

\section{Document analysis method}

In the present study, we approached the educational authorities and school operators through formal and informal means in Hong Kong, Shenzhen, Singapore, and Taipei to 
obtain the information about Chinese early childhood teacher compensation in their respective cities. In Shenzhen and Taipei, the compensation scales for public kindergartens were obtained from the government websites and government databases. Although Hong Kong does not have public kindergarten, the Education Bureau issued a recommended pay scale for non-profit-making kindergartens in 2007. The scale is still used by most of the kindergartens today (Li et al. 2013). In Singapore, the National Union of Trade Congress (NTUC) - the largest ECE service provider - provided their pay scale to the researchers. These official documents were cross-checked with other education officials (e.g., members of the education bureau), kindergarten practitioners (e.g., principals from the Kam Lai Kindergarten in Hong Kong and Lotus Kindergarten in Shenzhen), and university scholars (e.g., researchers from the SEED Institute in Singapore) to ensure their authenticity and comprehensiveness. Concrete examples of Hong Kong, Shenzhen, and Taipei kindergarten teacher salaries are presented in Additional file 1: Tables S1, S2, and S3 of this paper. The concrete example of Singapore teachers' salaries, however, is not presented in this paper, as it is not allowed to release to the public. Content analysis was conducted on these salary data to produce semi-quantitative results (see Tables 1, 2, 3, 4). Further clarification was sought from the corresponding educational officials, ECE scholars, or experienced educators whenever confusion or misconception in analyzing the official documents was encountered.

Document analysis includes the examination of excerpts, quotations, or entire passages from organizational, clinical, or program records; memoranda and correspondence; official publications and reports; personal diaries; and open-ended written responses to questionnaires and surveys (Patton 2005). It is an important social research tool in its own right and is an invaluable part of most schemes of triangulation. Bowen (2009) examined the advantages and limitations of document analysis, and offered specific examples of the use of documents in the research process. To make the cross-city comparison more reliable, we set up the key parameters for the document analysis: (1) Chinese early childhood teachers, (2) degree holders (if not available, associate degree holders), and (3) public kindergarten (if not available, non-profit kindergarten). In addition, the average number of working hours and the hourly paid salary were also analyzed.

\section{The Big Mac index}

The prices and living indexes vary greatly among the four cities, as do their currencies. It is therefore very difficult to compare the real purchasing power of the early childhood teachers' salaries. The BMI, however, is an ideal indicator for such a comparison. The Economist devised it and has consistently updated the BMI as an informal method

Table 1 Comparing the structure of the teacher compensation system across the four cities

\begin{tabular}{lccccl}
\hline City & Salary & Allowance (subsidy) & Incentive (bonus) & Benefits & Nature of the compensation \\
\hline Hong Kong & $\checkmark$ & $X$ & $X$ & $X$ & Single-salary scheme \\
Shenzhen & $\checkmark$ & $\checkmark$ & $\checkmark$ & $\checkmark$ & Competency- + performance-based \\
Singapore & $\checkmark$ & $X$ & $\checkmark$ & $\checkmark$ & Competency- + performance-based \\
Taipei & $\checkmark$ & $\checkmark$ & $\checkmark$ & $\checkmark$ & Competency- + performance-based \\
\hline
\end{tabular}


Table 2 Comparing public/non-profit preschool teacher monthly wages (in USD) across the four cities

\begin{tabular}{lccccc}
\hline City & Median wage & Starting wage & Maximum wage & $\begin{array}{c}\text { Working } \\
\text { hours/week }\end{array}$ & $\begin{array}{c}\text { Hourly wage } \\
\text { (median) }\end{array}$ \\
\hline Hong Kong & $2,248^{\mathrm{a}}$ & $1,606^{\mathrm{a}}$ & $2,952^{\mathrm{a}}$ & $44^{\mathrm{b}}$ & 12.77 \\
Shenzhen & 1,671 & 1,321 & 1,776 & 40 & 10.44 \\
Singapore & $1,508^{\mathrm{b}}$ & $971^{\mathrm{b}}$ & $1,830^{\mathrm{b}}$ & $44^{\mathrm{b}}$ & $8.57^{\mathrm{b}}$ \\
Taipei & 2,124 & 1,522 & 2,850 & 40 & $13.28^{\mathrm{a}}$ \\
\hline
\end{tabular}

${ }^{a}$ The best one among the four cities. ${ }^{\mathrm{b}}$ The worst one among the four cities.

of assessing purchasing power parity between different currencies. It was originally used to examine whether the exchange rate of two currencies is reasonable because it is based on the law of one price, meaning that all identical goods should have only one price in an efficient market (The Economist 2013). The McDonald's Big Mac hamburger is available in most countries around the world and is an internationally standardized product provided. Therefore, in theory, the Big Mac should have only one price in the world. Practically, however, the actual price of a Big Mac is vulnerable to the impact of taxes and business competition and thus cannot follow the law of one price. As a result, the BMI is an ideal indicator of food price and could be used to compare the purchasing power of salaries. Because the Big Mac prices of the four cities in this study are included in the BMI, we can use the measure to assess the adequacy of teacher compensation in terms of food expenses. Therefore, we use the most recent Big Mac Index (The Economist 2013) to compare the purchasing power in food with the median monthly salaries of early childhood teachers in each of the four cities.

\section{House price-to-income ratio}

House price-to-income ratio (HPI) is a measurement, devised in our previous paper, which serves as a useful index of purchasing power in housing (Li et al. 2013). Specifically, we compare the median salaries against the mean monthly rent for a one-bedroom apartment in the city center as well as in the suburb, resulting in two percentages. A higher percentage (for both city center and suburb) indicates a larger expenditure for rent; for example, a percentage of 55 means that an early childhood teacher is using $55 \%$ of her salary for rent - leaving less than half of her income for clothing, food, transportation, and other living needs. The mean monthly rent for all four cities are drawn from the most updated numbers from Numbeo (www.numbeo.com), an online database that provides cost-of-living information, based on figures submitted by

Table 3 Number of Big Macs bought with early childhood teacher monthly salaries (in USD)

\begin{tabular}{lccc}
\hline City & $\begin{array}{c}\text { EC teacher median monthly } \\
\text { wage }\end{array}$ & $\begin{array}{c}\text { Price of a Big Mac hamburger } \\
\text { (USD) }\end{array}$ & $\begin{array}{c}\text { Equivalent numbers of } \\
\text { hamburgers }\end{array}$ \\
\hline Hong & $2,248^{\mathrm{a}}$ & $2.19^{\mathrm{a}}$ & $1,026^{\mathrm{a}}$ \\
Kong & & & \\
Shenzhen & 1,671 & 2.57 & 650 \\
Singapore & $1,508^{\mathrm{b}}$ & $3.64^{\mathrm{b}}$ & $414^{\mathrm{b}}$ \\
Taipei & 2,124 & 2.54 & 850 \\
\hline
\end{tabular}

${ }^{\mathrm{a}}$ The best one among the four cities. ${ }^{\mathrm{b}}$ The worst one among the four cities. 
Table 4 House price-to-income ratio for early childhood teachers in the four cities

\begin{tabular}{lccccc}
\hline City & $\begin{array}{c}\text { Median } \\
\text { wage }\end{array}$ & $\begin{array}{c}\text { Mean monthly } \\
\text { rent in city center }\end{array}$ & $\begin{array}{c}\text { \% of EC teacher } \\
\text { monthly income }\end{array}$ & $\begin{array}{c}\text { Mean monthly rent } \\
\text { outside city center }\end{array}$ & $\begin{array}{c}\text { \% of EC teacher } \\
\text { monthly income }\end{array}$ \\
\hline Hong & $2,248^{\mathrm{a}}$ & 1,805 & $80 \%$ & 1,031 & $46 \%$ \\
Kong & & 955 & $57 \%$ & 578 & $35 \%$ \\
Shenzhen & 1,671 & $2,580^{\mathrm{b}}$ & $171 \%^{\mathrm{b}}$ & $1612^{\mathrm{b}}$ & $107 \%^{\mathrm{b}}$ \\
Singapore & $1,508^{\mathrm{b}}$ & $653^{\mathrm{a}}$ & $31 \%^{\mathrm{a}}$ & $525^{\mathrm{a}}$ & $25 \%^{\mathrm{a}}$ \\
\hline
\end{tabular}

${ }^{a}$ The best one among the four cities. ${ }^{\text {b}}$ The worst one among the four cities.

individuals, for cities around the world. Numbeo regularly publishes online global living index, price index, the rent index, and the world's major countries and cities housing rent data. It is a more comprehensive and reliable global price database for price comparison ( $\mathrm{Li}$ et al. 2013). Therefore, we use the most recent Numbeo data (published in 2013) to compare the purchasing power in housing with the median monthly salaries of Chinese early childhood teachers in the four cities.

\section{Results}

In this study, we reviewed the public (non-profit) kindergarten teacher compensation systems across four featured cities in the following three ways. First, we compared the existing compensation systems to identify the most comprehensive and inclusive structure, checking whether these systems include base salary, allowance, incentives, and cash-based benefits. Second, we used a common currency (U.S. dollars) to compare the actual salaries of early childhood teachers to understand which city provides the best pay for early childhood teachers. Third, we calculated the real purchasing power of teacher monthly income using both the BMI (The Economist 2013) as well as the HPI (Li et al. 2013). Through these comparisons, both across the featured cities as well as in relation to the two indices, we aim to provide an introductory as well as preliminary examination into the compensation of Chinese early childhood teachers.

\section{Comparing the compensation structure among four cities}

First, we focused on the structure of teacher compensation for the public kindergartens, with the exception of Hong Kong and Singapore. As there are no public kindergartens in the two cities, we base our research instead on the teacher compensation for non-profit-making kindergartens - the closest type of kindergarten to a public one, as well as the most common type of kindergarten, in the two cities (Li et al. 2012). This study is attempting to explore the maximum level rather than a broad range census of the earning power of early childhood teachers. Because for-profit private kindergartens tend to underpay their teachers ( $\mathrm{Li}$ et al. 2013), it is very difficult to compare teacher compensation in the private sector. Therefore, this study can only review the most ideal compensation structures that currently exist in the four cities.

Table 1 provides a breakdown of the teacher compensation structure - including salary, allowance, incentive, and benefits - across the four cities. As shown in Table 1 and Additional file 1: Tables S1, S2, and S3, the structure of teacher compensation system varies from city to city. Of the four cities, Taipei appears to have the most comprehensive and inclusive structure of compensation, with allowances, incentives, and benefits provided to the 
teachers in addition to a base salary (plus research subsidy), which is based on teacher's ranking (competencies). All the incentives in Taipei are performance-based and tend to take the form of additional cash provided at the end of the year; allowances often cover transportation, housing, and children education; and benefits include additional fees to support research and attending important life events (e.g., weddings and funerals). The early childhood teacher compensation systems in Shenzhen and Taipei are similar to the compensation system for primary and secondary school teachers. Singapore teachers can get incentives/allowances and benefits in addition to their base salary. Hong Kong early childhood teachers appear to fare the worst, relying on only a basic single pay scale as compensation for their work.

Next, we compared the actual monthly pay across the four cities. Table 2 lists the starting, median, and maximum salaries (in U.S. dollars) for an early childhood teacher with a bachelor's degree or the equivalent, as well as the number of working hours per week and the subsequent hourly median pay for that teacher. Examination of Table 2 reveals a slightly different picture of the ECE landscape in these cities. In terms of base salaries, early childhood teachers in Hong Kong appear to be the most generously compensated for their work. But it is very important to note that this is a single-salary pay, which has no allowance, incentives, and benefits, except for Mandatory Provident Fund (MPF), the compulsory retirement saving contributed by employers (See Additional file 1). By contrast, Chinese early childhood teachers in Singapore appear to be the most poorly compensated for their work, earning the least amount of money for their work and having one of the longest work weeks, resulting in an hourly median salary of 8.57 U.S. dollars. The salaries of the other two cities - Shenzhen and Taipei - range between Singapore and Hong Kong.

Considering the first two tables together, we see that early childhood teachers in Taipei have the most comprehensive and inclusive structure of compensation and the best hourly pay for their work, whereas Hong Kong teachers receive the highest level of compensation for their work. And the compensation for early childhood teachers in Singapore falls behind other cities. To gain a more comprehensive picture of the adequacy of the teacher compensation system in the four cities, we compare the monthly pay level with two standard-of-living measures: the BMI and the HPI.

\section{Comparing teacher pay level with the comparable indicators}

As seen in Table 3, the price of a Big Mac hamburger varies between the cities. The price of a hamburger is the lowest in Hong Kong and the highest in Singapore. Accordingly, Hong Kong early childhood teachers would be able to afford the most number of hamburgers due to their high salaries and the low price. On the other hand, Singaporean teachers, who earn the lowest salary and must pay the highest amount for a hamburger, would be able to afford the least amount of food. The numbers for the other two cities fall in between: early childhood teachers in Shenzhen and Taipei, in particular, benefit from relatively low Big Mac prices.

As shown in Table 4, the HPI indicates that the early childhood teachers who earn the median salaries in Taipei would be able to rent a one-bedroom apartment, both in and outside the city center. And they have at least two-thirds of their incomes left over to spend on other living needs. But Hong Kong and Shenzhen early childhood teachers 
who earn the median salaries would be able to afford living outside the city center, while living in the city center would require over half of their income; the mean monthly rent in the Hong Kong city center, in particular, would occupy $80 \%$ of a teacher's income.

Of the four cities, Singaporean early childhood teachers appear to fare the worst: teachers who earn the median salaries are unable to afford even a one-bedroom apartment outside the city center, even if they put all of their income towards the rent. This is partly affected by the unique housing market in Singapore, which is mainly divided into two categories, namely private condominiums and House Development Bureau (HDB) flats. More than $80 \%$ of Singaporeans live in HDB house. The one-room HDB apartment is available only to its own citizens; permanent residents and foreigners can only rent two-bedroom or a bigger apartment from the private market. Most of the Chinese early childhood teachers in Singapore are foreigners or newly arrived permanent residents, hailing from mainland China, Taiwan, and other countries. Because Numbeo reports numbers only for private apartments, housing appears to be more expensive, possibly leading to an apparently lower purchasing power in housing for early childhood teachers in Singapore.

\section{Discussion}

If young children have a right to quality early childhood education, their teachers, who are responsible for the early formation of these children's minds, should also have the right to a fair and adequate compensation for their efforts. How much we pay the teachers reflect what value we place on our young children. It is really debatable what is fair or adequate, however, as one might argue that early childhood teachers should earn even more than primary and secondary school teachers because they are nurturing younger children and carrying more responsibilities. In this section, we will elaborate more on the results of this study to understand how fair those kindergarten teachers are compensated when comparing with their counterparts in other Chinese cities.

\section{How do the compensation systems compare with one another?}

The present study found that the compensation of early childhood teachers in Hong Kong is the simplest system in the four cities. It is a single-salary scheme and does not include any allowances, bonuses, or benefits. The salary point increases with a teacher's work experience and competencies and is also regulated by the market, not by performance (Li et al. 2013). Kindergarten principals cannot modify a teacher's pay based on their performance. By depending so heavily on the single-salary scheme, Hong Kong kindergartens have not been able to leverage incentives to retain high performers and shed low performers. A more efficient pay structure should focus on retaining the best teachers while eliminating instructors who fail to meet expectations. Therefore, this finding implies that there is a need to reform the early childhood teacher compensation system in Hong Kong.

By contrast, the other three cities feature a mixture of competency-based and performance-based compensations for their public or non-profit-making school teachers, which primarily reflect a teacher's professional level, skills, or other competencies. In addition, some performance-related rewards or incentives are offered to reflect a teacher's performance. This finding indicates that the mainstream compensation structure for 
Chinese teachers is a mixture of competency- and performance-based compensations. This mixed compensation system includes professional development allowances for financing teacher's in-service training and continuing education studies, wedding allowance, birth allowance, transport allowance, housing allowance, and allowances for their children's education. Why is this mixed compensation a preferable one in Chinese societies?

First, basing the pay scheme on teacher performance in the classroom would be ideal, since teachers could be better motivated to teach more effectively (OECD 2012). But practically, it is not easy to implement such a performance-based pay system, as it needs systematic and reliable measures to evaluate teacher performance (Rowland and Potemski 2009). In addition, performance evaluations may lead to increased competition among teachers, discouraging them from working as members of a team and forcing them to perform according to the performance indicators being used (i.e., teach to the test) (Podgursky and Springer 2007). Therefore, all the cities here employed (primarily) the competency-based pay scheme, which relates salary progression (and sometimes a cash bonus) to the competencies of teachers. The agreed framework of competencies varies among the cities but mostly includes obtaining a bachelor's degree (usually in education), a postgraduate certification, or taking on a new role (e.g., class teacher, head teacher) in kindergarten. The competency-based pay scheme, however, is not used in a pure form as the only means for determining reward, as the acquisition of certain competencies will not necessarily translate into better performance in teaching (Brown and Armstrong 1999). Therefore, three of the researched cities combined the competency-based and performance-based compensation system to better reward a teacher's contribution. Only Hong Kong chose to follow the single-salary scheme, which is totally based on teachers' competencies. The prevalence of this mixed compensation system across these cities suggests that such a system is the most suited to Chinese early childhood teachers.

\section{Which city pays the most to early childhood teachers?}

The current study found that Taipei featured the most comprehensive compensation structure and the highest level of hourly pay, the shortest working hours, as well as the strongest purchasing power in housing. By contrast, Singapore features the lowest pay level, the longest working hours, and the weakest purchasing power in food and housing. It is unsurprising to find a more comprehensive teacher compensation system in Taipei as they have invested more resources in the ECE system than other cities, providing teachers with the means to make a living. In the cities where governmental influence is more limited - Hong Kong and Singapore - teacher compensation is less adequate. The insufficient teacher compensation in Hong Kong and Singapore, relative to their counterparts, is worrying, as it discourages potential high-quality candidates from pursuing or remaining in the ECE field. And there might be some sociohistorical, cultural, or political factors contributing to the differences between Hong Kong/Singapore and the other cities.

Sociohistorically, Singapore and Hong Kong share many commonalities. Most noticeably, they were both colonized by the British, who left the early childhood education system mostly to the free market (Rao and Li 2009). Over the years, ECE continued to be undervalued and excluded from the compulsory education system. Thus, no public kindergartens were established in Hong Kong and Singapore, even after post-colonial 
educational authorities were in place (Rao and $\mathrm{Li}$ 2009). But in recent years, the importance of ECE has been recognized, especially by governmental officials, who are eager to raise the quality of national ECE services to international standards ( $\mathrm{Li}$ et al. 2013). However, the ECE systems in Hong Kong and Singapore remain privatized and largely independent of governmental monitoring; thus, early childhood teachers especially those Chinese teachers tended to be underpaid and unfairly treated. Substantial reform, including an implementation of a more complex competency- and performance-based compensation system, may be needed to improve the ECE field in the two cities. Fortunately, the educational authorities in Hong Kong and Singapore have recently invested so much into the development of ECE and some attention has been paid to the compensation problems. Hong Kong government, for example, has just set up the Committee on Free Kindergarten Education to thoroughly review and systematically develop its ECE policies.

\section{Limitation of the study}

There are several limitations of this study. One of the most critical issues is that we only analyzed the compensation of early childhood teachers in four Chinese societies, with a focus on public kindergartens (or non-profit private kindergarten in Hong Kong and Singapore). It is important to note that very little is known about the private, kindergarten sector. Anecdotal evidence suggests that teachers employed by profit-making kindergartens are severely underpaid, especially compared to their counterparts working in non-profit or public kindergartens ( $\mathrm{Li}$ et al. 2013). However, more studies are needed to understand the actual situation. For instance, we can further understand whether these early childhood teachers' compensation is comparable to those given to primary and secondary school teachers in future studies. Additionally, although the $B M I$ and the HPI provide cursory insights into the adequacy of ECE teacher compensation, other factors - such as the costs of transportation, grocery shopping, and clothes purchases - should also be considered in the future. In addition, the skewed sample of this study could not support a more generic and precise comparison; thus, it is unable to provide a clear map of teachers' working conditions in the four cities. Ideally, we would be able to compare the working conditions of early childhood teachers among the four cities, but as working and vacation hours vary across cities, such a comparison would require a substantially more thorough investigation. Nevertheless, many early childhood teachers are married with a family; thus, they really need to rent twobedroom apartments to maintain a comfortable family life. But this is really beyond their affordability, especially in Hong Kong and Singapore, the most globalized and attractive cities in East Asia. Further studies, particularly those with large-scale samples and in-depth interviews of the various ECE stakeholders (e.g., teachers, kindergarten owners, and policymakers), are needed to understand the real working conditions of Chinese early childhood teachers.

\section{Conclusions}

This study provides a preliminary description of how Chinese teachers in the ECE field are compensated for their work. Hong Kong employs a single-salary scheme, whereas the other cities use a mixture of competency-based plus performance-based compensation. Taipei teachers get the best pay and accordingly the strongest purchasing power 
in terms of housing, whereas Singapore teachers get the lowest pay and consequently the weakest purchasing power. We have discussed the basic breakdown of the teacher compensation system in each city, with a basic understanding of what allowances, incentives, and benefits are given to early childhood teachers. But there are still numerous private kindergartens being run in all the four cities, understanding how teachers are compensated in the private education sphere is vital. In sum, there is still much work to do to improve teacher compensation in ECE to recruit, attract, and retain high-quality early childhood teachers. Our paper only provides the very first investigation into how Chinese early childhood teachers are paid in four cities - one that we hope will encourage more studies to follow. Accordingly (and hopefully), more comprehensive and inclusive structure and higher level of compensation could be implemented to enhance the quality and stability of early childhood teachers, the most important corner stone of quality early childhood education.

\section{Additional file}

Additional file 1: Tables S1, S2, and S3. Table S1. Compensation structure and level of Hong Kong non-profitmaking kindergarten teachers (in Hong Kong dollar). Table S2. Compensation structure and level of Shenzhen public kindergarten teachers (in RMB). Table S3. Compensation structure and level of Taipei public kindergarten teachers (in New Taiwan currency).

Competing interests

The author declares that he has no competing interests.

\section{Acknowledgements}

We would like to thank the following people for their contribution to this project: Dr. Eva Chen, Ms. Christina Ahn, Prof. Kiyomi Akita, Ms. Lilian Chau, Ms. Ho Yin Fong, Prof. Yu-Wei Lin, Mr. Han-Wen Liu, Dr. Connie Lum, Ms. Ginia Ng, and Prof. Eunhye Park. We also thank the principals and teachers of Shenzhen Lotus Kindergarten and Hong Kong Buddhist Kam Lai Kindergarten for their kind help.

Received: 13 March 2014 Accepted: 12 August 2014

Published online: 08 October 2014

\section{References}

Bowen, GA. (2009). Document analysis as a qualitative research method. Qualitative Research Journal, 9(2), 27-40. Brown, D, \& Armstrong, M. (1999). Paying for contribution: real performance-related pay strategies. London: Kogan Page Limited. Howes, C, \& Hamilton, CE. (1993). The changing experience of child care: changes in teachers and in teacher-child relationships and children's social competence with peers. Early Childhood Research Quarterly, 8, 15-32.

International Labour Organization. (2012). Right beginnings: early childhood education and educators. Geneva: The Author

Koppich, J. (2008). Toward a more comprehensive model of teacher pay. Nashville: National Center on Performance Incentives. Retrieved May 20, 2013, from https://my.vanderbilt.edu/performanceincentives/files/2012/10/ 200806_Koppich_CompModelTeacherPay.pdf

Li, H. (2012). Compensation of kindergarten teachers in Hong Kong: problems and proposals. Early Childhood Education (Educational Sciences), 562(10), 1-13. in Chinese.

Li, H, Wong, JMS, \& Wang, XC. (2008). Early childhood education voucher in Hong Kong: perspectives from online communities. International Journal of Early Childhood, 40(2), 49-63.

Li, H, Wong, MS, \& Wang, XC. (2010). Affordability, accessibility, and accountability: perceived impacts of the pre-primary education vouchers in Hong Kong. Early Childhood Research Quarterly., 25(1), 125-138.

Li, H, Rao, N, \& Tse, SK. (2012). Adapting Western Pedagogies into Teaching Chinese Literacy: case studies of Hong Kong, Shenzhen and Singapore Preschool Classrooms. Early Education and Development, 23(4), 1-19.

Li, H, Chen, E, \& Lin, Y. (2013). A comparison of kindergarten teacher compensation between Shenzhen, Hong Kong, and Taipei. Early Childhood Education (Educational Sciences), 577(3), 9-13. in Chinese.

Neathey, F, \& Reilly, P. (2003). Competency-based pay. The Institute for Employment Studies. Retrieved May 20, 2013, from http://www.employment-studies.co.uk/pdflibrary/mp25.pdf.

$\mathrm{Ng}$, J. (2011). Preschool curriculum and policy changes in Singapore. Asia-pacific Journal of Research in Early Childhood Education, 5(1), 91-122.

OECD. (2012). Does performance-based pay improve teaching? PISA in Focus, 16(5), 1-4.

Patton, MQ. (2005). Qualitative Research. In BS Everitt \& DC Howell (Eds.), Encyclopaedia of statistics in behavioural science (Vol. 3, pp. 1633-1636). Chichester: John Wiley.

Podgursky, M. (2007). Team versus bureaucracies: Personnel policy, wage-setting, and teacher quality in traditional public, charter, and private schools. In M Berends, MG Springer, \& H Walberg (Eds.), Charter School Outcomes. Mahwah, NJ: Erlbaum 
Podgursky, M, \& Springer, M. (2007). Teacher performance pay: a review. Journal of Policy Analysis and Management, 26(4), 909-949.

Podgursky, M, \& Springer, M. (2011). Teacher compensation systems in the United States K-12 school system. National Tax Journal, 64(1), 165-192.

Rao, N, \& Li, H. (2009). Quality matters: early childhood education policy in Hong Kong. Early Child Development and Care, 179(3), 233-245.

Rowland, C, \& Potemski, A. (2009). Alternative compensation terminology: considerations for education stakeholders, policymakers, and the media. Washington D.C., USA: Learning Point Associates.

The Economist. (2013). The Big Mac index. Retrieved January 30, 2013, from http://www.economist.com/content/bigmac-index.

Thornburg, K, Raikes, H, Wilcox, B, Edwards, CP, \& Torquati, J. (2005). Policy brief: compensation of early childhood teachers: what value do we place on young children? Lincoln, USA: DigitalCommons@University of Nebraska-Lincoln.

Whitebook, M, Sakai, L, Gerber, E, \& Howes, C. (2001). Then and now: changes in child care staffing, 1994-2000. Technical report. Washington DC: Center for the Child Care Workforce.

doi:10.1007/s40723-014-0002-7

Cite this article as: Li: Compensation of Chinese early childhood teachers: a preliminary study in Hong Kong,

Shenzhen, Singapore, and Taipei. International Journal of Child Care and Education Policy 2014 8:2.

\section{Submit your manuscript to a SpringerOpen ${ }^{\circ}$ journal and benefit from:}

- Convenient online submission

- Rigorous peer review

- Immediate publication on acceptance

- Open access: articles freely available online

- High visibility within the field

- Retaining the copyright to your article

Submit your next manuscript at $\boldsymbol{\nabla}$ springeropen.com 